\title{
Assessing the Institutional Outreach and Sustainability of Micro Finance Institutions in Ethiopia: Evidence from Omo Microfinance Institution Hawassa Branch
}

\author{
Mathewos Yure Dangisso, Kanbiro Orkaido Deyganto \\ Furra Institute of Development Studies and Education, Furra College Hawassa Gudamale Campus, Yirgalem, Ethiopia
}

Email address:

mathewosyure598@gmail.com (M. Y. Dangisso),kanbiro.orkaido@gmail.com (K. O. Deyganto)

\section{To cite this article:}

Mathewos Yure Dangisso, Kanbiro Orkaido Deyganto. Assessing the Institutional Outreach and Sustainability of Micro Finance Institutions in Ethiopia: Evidence from Omo Microfinance Institution Hawassa Branch. American Journal of Theoretical and Applied Business. Vol. 6, No. 1, 2020, pp. 1-5. doi: 10.11648/j.ajtab.20200601.11

Received: March 2, 2020; Accepted: March 19, 2020; Published: April 30, 2020

\begin{abstract}
Institutional sustainability and outreach are key issues in micro finance institutions. So, the objective of this study was to assess the institutional outreach and sustainability of Omo Microfinance Institution Hawassa branch. To this end, the researchers used descriptive research design because using this type of research design enables the researchers to assess and describe the present situation of institutional sustainability and outreach of the institution. The primary data was collected from sixty respondents using structured questionnaire. Then, descriptive statistics analysis has been done through SPSS version 20.0 in order to get the reliable findings. Consequently, the result of this study showed that the level of sustainability and institutional outreach is improved by deposit and saving mobilization. Besides, this study revealed that the outreach and sustainability of OMFI Hawassa branch were influenced by constraints such poor loan management, flexibility of loan repayment schedule, and loan defaulting faced by customers. Based on the findings of the study, the researchers forwarded possible recommendations for the OMFI Hawassa branch in order to improve the institutional sustainability and outreach.
\end{abstract}

Keywords: Omo Microfinance Institution, Sustainability, Outreach, Hawassa, Ethiopia

\section{Introduction}

\subsection{Background of the Study}

Microfinance refers to the delivery of financial services such as credit, savings and insurance for lower income society in the nation. Accordingly, Ethiopian Proclamation No. 626/2009 defines micro financing business as "the provision of financial services like accepting savings extend credit, drawing and accepting drafts payable, providing money transfer services and others specified in the Article 3 (2) of the proclamation. Besides, [1] defined microfinance as a provision of financial services to low income clients or solidarity lending groups including consumers and the self-employed, who traditionally lack access to banking and related services.

The two aspects on which OMFIs concentrates are outreach to all society and its sustainability in performing financial services. Outreach- is progress toward the mission of development finance. This mission is to make the lives of poor people better. MFIs do this by producing outreach, loans and deposits used by the poor. It refer to the effort by micro finance organizations to extend loans and financial services to an ever-wider audience (breadth of outreach) and especially toward the poorest of the poor (depth of outreach). Thus, reaching the poorest is depth of outreach, but reaching large number of people even if they are relatively less poor is breadth of outreach. Sustainability- is the ability to repeat outreach in the future MFIs differ from banks because they provide financial services to low income customers and often provide loans based on group based collateral. It can be defined as the capacity of a program to stay financially viable even if subsidies and financial aids are cut off by reducing expenses per loan and increasing the probability of repayment. Hence, studying outreach and sustainability of OMFIs is an important agenda of 21th century.

\subsection{Statement of the Problem}

The prevailing operation of the OMFIs in low income 
countries like Ethiopia is inefficient in providing sustainable credit facilities to the poor due to limited outreach and financial sustainability. Access to institutional credit, which contributes to the increase in investment, is very limited in Ethiopia particularly in Hawassa city. In other way, [2] found that financial services accessible to the rural poor might have the potential to efficiently contribute to income generation, food security and poverty alleviation.

Even if the institutional sustainability and outreach of micro finance institution is burring agenda, few research has been conducted same topic in other parts of Ethiopia. For instance, [12, 10, 1, 3] then suggested that institutional outreach and sustainability has positive influence on organizational performance of Omo microfinance institution in particular and contributes to the economic development of the nations.

But no research has been conducted in OMFI Hawassa branch with the same topic and the researcher has information about the problems related to institutional outreach and sustainability of OMFI in the city. This is why the researchers have motivated to conduct this research work.

\subsection{Objectives of the Study}

The general objective of this study is to assess the institutional outreach and sustainability of Omo microfinance institution at Hawassa.

Following general objective, the specific objectives of Study are:

1. To assess the sustainability and outreach level of OMFIs Hawassa branch.

2. To assess saving mobilization services of OMFI in building sustainable and outreach.

3. To assess factors affecting outreach \& sustainability of OMFI Hawassa Branch.

\subsection{Literature Review}

\subsubsection{Concept of Financial Sustainability}

When the microfinance concept begun exhibiting significant growth trends policy makers and other interested parties including donors started advocating for profitability from these institutions. Financial Sustainability is a key and arguably the most significant dimension of microfinance sustainability. Financial sustainability is the ability to continue with the microfinance objectives without sustained donor aid. Financial sustainability can also be explained by the ability of a Microfinance Institution in covering operational as well growth expenses from income derived from its own activities. An OMFI is said to be operationally sustainable if it can absorb its operation expenses from its own operations even if it is not subsidized. Financial Self-sufficiency on the other hand is when an OMFI is able to its operational and financing costs at market prices [4].

According to study by [3], MFI self-sufficiency can be equated to nonprofit equivalent of profitability. A MFI that is able to cover the cost on non- cash expenses including the cost of inflation and at the same time has the ability to continue its operations without grants or subsidized inputs is said to have attained self-sufficiency In this study, the researcher uses OSS ratio to measure Microfinance financial sustainability.

Pursuit of financial sustainability has necessitated some MFIs to adopt approaches such as the gathering of Market intelligent and introduction of cost cutting measures aimed to checking the market forces and increasing efficiency which eventually leads to sustainability [7].

Poverty alleviation has been one of the key development challenges over the decades in most developing economies. One of the identified key constraints faced by the poor is lack of access to formal credit. Microfinance institutions were established to fill the gap of scarce finance resources by providing funds to the poor and lower income group to alleviating poverty and enhance their business activities. Different approaches have been employed in alleviating poverty; the one is provision of credit for targeted poor. Credit is considered to be an essential input to increase productivity [9].

\subsubsection{Concept of Outreach}

Microfinance outreach is viewed in two major aspects; number of poor people microfinance can reach (Depth) and number of people served by MFI without necessarily considering their poverty levels (Breadth). In other words the depth of microfinance can be viewed in light of poverty levels of the people reached. This aspect can also be referred to as the social impact objective of Microfinance since it views Microfinance as a poverty alleviation tool. Proponents of this definition argue that a financial institution that disregard the economic status of the clients or does not consider the poor in their lending or financial services provision is no longer microfinance but rather a bank [4].

On the other hand, outreach in terms of breadth can be defined as the scale of the microfinance institution in question without necessarily putting into consideration the economic status of the person. MFIs breadth can be defined as the ability of a MFI to reach a wide range of clients [6].

Other Scholars such as $[13,12]$ argue that in the microfinance field large number of clients in good standing enhance financial sustainability. The Institutions are Concerned about advancing access to a wider net clients not adequately served, further arguments suggest that sustainability is a means to attain outreach. Bearing in mind the possibility of MFIs services not reaching the majority of the poor populations, research and scholars have demonstrated that they are likely to benefit from the spillover effects. Some of such spillovers are manifested through employment opportunities, higher standards of living by family members and associates accruing to those establish enterprises and other income generating activities from micro credits advanced [2].

\section{Methodology}

\subsection{Research Design and Approach}

Research Design: This study was employed research descriptive research design because the objective of this 
study was to describe institutional sustainability and outreach of OMFI Hawassa branch.

Research Approach: The study also employed mixed research approach due to qualitative and quantitative nature of the data.

\subsection{Data Type and Source, Methods Collection and Analysis}

Data type and source: This study was conducted based on both primary and secondary data types. The primary data sources were employees of OMFI but secondary data sources were Annual reports of OMFI and other published and unpublished materials.

Methods Collection and Analysis: The primary data were collected through structured questionnaires. After collection of the necessary data, it has been analyzed through descriptive statistics and presented in table form.

\subsection{Target Population, Sample Size and Sampling Techniques}

Target Population: Target population of the study was 136 employees of OMFI Hawassa Branch.

Sample Size and Sampling Techniques: The sample size for this study was 101 respondents drawn from the total population of 136 OMFI Hawassa branch using simple random sampling technique.

Sample size determination: Sample size of study was determined using formula [14] and calculated below.

$$
n=\frac{N}{1+e^{2} * N}
$$

Where: $\mathrm{n}=$ sample size

$\mathrm{N}=$ population size

$\mathrm{e}=$ Precision level or sampling error $=0.05$

In order to take the sample from 136 employees of OMFI Hawassa by applying the above formula as follow:

$$
n=\frac{136}{1+(0.05)^{2} * 136}=101
$$

\subsection{Ethical Consideration}

Ethical consideration: The ethical considerations such as voluntary participation of respondents, no harm to participants, confidentiality of data, and privacy of participants involved in this study have been given attention by the researchers.

\section{Presentation of Results}

In order to conduct data analysis, the researcher distributed one hundred one (101) questionnaires to respondents. Out of the 101 questionnaires distributed, sixty (60) questionnaires were correctly filled and returned. This implies that the response rate of the research was fifty nine point four $(59.40 \%)$ which indicates more than half of respondents were participated in the process of data collection. Then, the descriptive statistical analysis has done using the statistical package for social science version 20.0 using questionnaires properly collected.

\subsection{Reliability Test}

Table 1. Reliability Test of the study.

\begin{tabular}{ll}
\hline Cronbach's Alpha & No. of Items \\
\hline 0.706 & 14 \\
\hline Source: Personal survey, 2020. &
\end{tabular}

From the above table 1, the value for Cronbach's Alpha $(\alpha)$ was 0.706 for all items. When these calculated reliability value is more 0.70 which acceptable, and compared with the minimum value of alpha 0.70 advocated by [8] then the responses generated for all of the variables 'used in this research were reliable enough for data analysis. This implies that the data incorporated in SPSS version 20.0 is reliable and can be base for analysis.

\subsection{The Level of Sustainable and Outreach of OMFI of Hawassa Branch}

Table 2 The level of sustainable and outreach of OMFI of Hawassa branch.

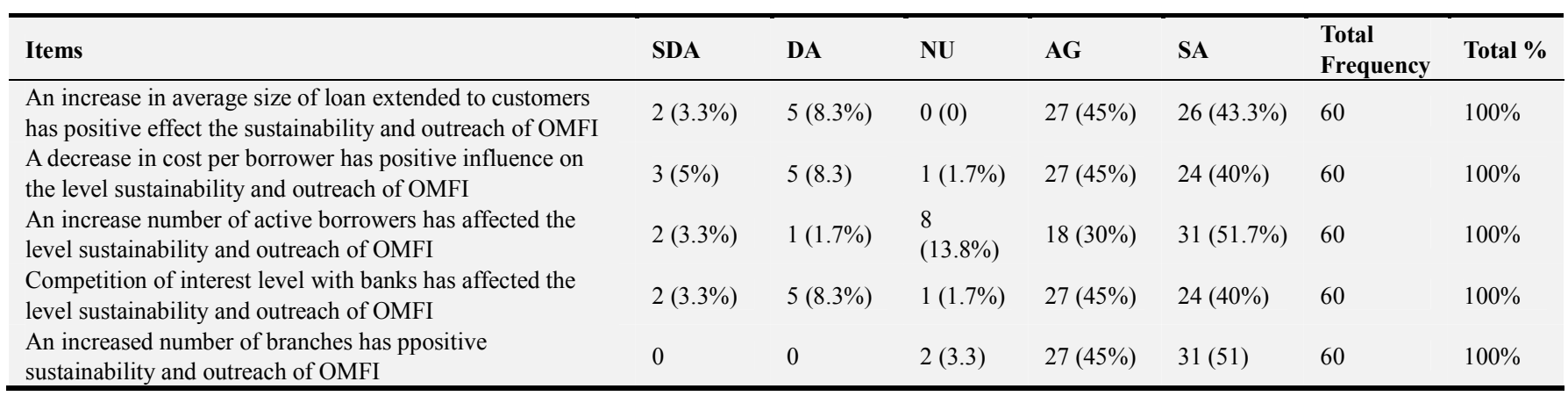

Source: Personal survey, 2020.

The above table 2 shows that the level of sustainable and outreach of OMFI Hawassa branch measured on five point Likert scale is good on average. Hence, most of the respondents agreed on the statements such as; an increase in average size of loan extended to customers 53 (88.3\%), a decrease in cost per borrower has positive influence 51 
$(85 \%)$, an increase number of active borrowers $49(81.7 \%)$, competition of interest level with banks $51(85 \%)$ and an increased number of branches $58(96 \%)$ has positive implication of sustainability and outreach of OMFI respectively.

\subsection{Saving Mobilization Services of OMFI as a Means of Building Sustainable and Outreach}

As displayed in the following table 3, Saving mobilization services of OMFI as a means of building sustainable and outreach is positive on average as far as the most of respondents agreed on the statements such as; higher deposit mobilization has positive influence on the sustainability of profit margin of OMFI 54 (92.6\%), build saving mobilization extended to borrowers has affected the outreach and sustainability $49(81.7 \%)$, increase in saving amount has affected the outreach and sustainability 47 (78.4\%) and regulatory saving framework has affected the outreach and sustainability $50(83.3 \%)$ of your MFI respectively.

Table 3. Saving mobilization services of OMFI as a means of building sustainable and outreach.

\begin{tabular}{|c|c|c|c|c|c|c|c|}
\hline Items & SD & DA & $\mathbf{N U}$ & $\mathbf{A G}$ & SA & $\begin{array}{l}\text { Total } \\
\text { Frequency }\end{array}$ & $\begin{array}{l}\text { Total } \\
\text { Percentage }\end{array}$ \\
\hline $\begin{array}{l}\text { Higher deposit mobilization has positive influence on } \\
\text { the sustainability of profit margin of OMFI }\end{array}$ & $0(0 \%)$ & $2(3.3 \%)$ & $3(5 \%)$ & $28(49.3 \%)$ & $26(43.3 \%)$ & 60 & $100 \%$ \\
\hline $\begin{array}{l}\text { Build saving mobilization extended to borrowers has } \\
\text { affected the outreach and sustainability of your MFI }\end{array}$ & $\begin{array}{l}2 \\
(3.3 \%)\end{array}$ & $1(1.7 \%)$ & $8(13.5 \%)$ & $18(30 \%)$ & $31(51.7 \%)$ & 60 & $100 \%$ \\
\hline $\begin{array}{l}\text { Increase in saving amount has affected the outreach and } \\
\text { sustainability of your OMFI }\end{array}$ & 3 (13.6) & $3(13.6)$ & $3(13.6)$ & $16(26.7 \%)$ & $31(51.7 \%)$ & 60 & $100 \%$ \\
\hline
\end{tabular}

Source: Personal survey, 2020.

\subsection{Factors Affecting Outreach \& Sustainability of OMFI Hawassa Branch}

Table 4. Factors affecting outreach \& sustainability of OMFI Hawassa branch.

\begin{tabular}{|c|c|c|c|c|}
\hline Items & Agree & Disagree & $\begin{array}{l}\text { Total } \\
\text { Frequency }\end{array}$ & $\begin{array}{l}\text { Total } \\
\text { percent } \%\end{array}$ \\
\hline Nature of loan extended to customers is affects the outreach and sustainability of your MFI. & $60(100.0 \%)$ & $0(0 \%)$ & 60 & $100 \%$ \\
\hline Poor loan management has negative affect the outreach and sustainability of your MFI. & $48(80.0 \%)$ & $12(20.0 \%)$ & 60 & $100 \%$ \\
\hline $\begin{array}{l}\text { Flexibility of loan repayment schedule extended to the customers has effect on the } \\
\text { sustainability of turnover of your MFI }\end{array}$ & $47(78.3 \%)$ & $13(21.7 \%)$ & 60 & $100 \%$ \\
\hline $\begin{array}{l}\text { Consequence of loan defaulting faced by customers has undesirable effect on the } \\
\text { sustainability of your MFI }\end{array}$ & $60(100.0 \%)$ & $0(0 \%)$ & 60 & $100 \%$ \\
\hline Poor follow up and monitoring & $44(73.3 \%)$ & $16(26.7 \%)$ & 60 & $100 \%$ \\
\hline
\end{tabular}

Source: Personal survey, 2020.

As it can be easily seen from the above table 4 , the nature of loan has its own consequences on sustainability and outreach refilled $60(100 \%)$ respondents agreed that the nature of loan is one of the factors affecting sustainability and outreach. Poor loan management as one factor affecting the outreach and sustainability of OMFI. Because, out of 60 sample respondents, $48(80.0 \%)$ agreed that poor loan management has negative affect the outreach and sustainability OMFI but only $12(20.0 \%) \%$ disagree with statement poor loan management has negative affect the outreach and sustainability. Flexibility of loan repayment also as a one of factors affecting sustainability and outreach. Because, 47 (78.3\%) agree with flexibility of loan repayment schedule extended to the customers has effect on the sustainability of turnover of OMFI but, 13 (21.7\%) who disagreed with statement flexibility of loan repayment schedule extended to the customers has effect on the sustainability of turnover of OMFI. The consequences of loan defaults faced its own magnitudes on sustainability and outreach fill up $60(100 \%)$ respondents agreed that the nature of loan is one of the factors affecting sustainability and outreach. but no any respondent opposed the statement as it has supported by $0(0 \%)$ disagree with statement. Finally, when it comes to per customer outstanding as one of factors affecting the outreach and sustainability of OMFI, majority of the respondents $44(73.3 \%)$ agreed on the statement that stated poor follow up and monitoring is one of factors affect the outreach and sustainability of OMFI whereas $16(26.7 \%)$ of the respondents disagreed with the statement.

\section{Conclusion}

Based on findings of this study, the following conclusions has been made by the researchers:

The level sustainable and outreach of OMFI, the researchers were concluded that increase in average size of loan extended to customers, decrease in cost per borrower, increased number of active borrowers, saving and deposit mobilization and having regulatory saving framework improve the sustainability and outreach of OMFI Hawassa branch.

With regards to factors influencing outreach and sustainability of OMFI, the researchers can conclude that nature of loan extended to customers, poor loan management., 
flexibility of loan repayment schedule extended to the customers, consequence of loan defaulting faced by customers, and poor follow up and monitoring were among the major factors that influence the outreach and sustainability of OMFI Hawassa branch.

\section{Direction for the Further Research}

a) At first, this study focused only on assessing the institutional sustainability and outreach of OMFI Hawassa branch out of five microfinance institutions operating in Hawassa city. Consequently, the findings of this study may be difficult to generalize about all MFIs in the city, in all regions and at national level.

b) Hence, this study will be improved if it will be done at other regions and national level by comparing the factors affecting operational effectiveness of OMFI and other micro finance institutions by increasing sample size.

c) It can improved if other researchers adopt model to identify factors affecting the institutional sustainability and outreach of microfinance institutions in all regions and country level which may increase the level of reliability of findings as far as the current study only used descriptive statistics for analyzing data collected from questionnaire of OMFI Hawassa branch.

d) Also can be done on the same topic by employing the econometric model by scientifically discuss the determinants of OMFI institutional sustainability and outreach based audited financial statement as the current study does not concentered on audited financial statements and not employing econometric model in analyzing data.

\section{Acknowledgements}

First of all, we would like to give unlimited thanks for God for giving us capacity and chance to complete this research paper. Next to God, we appreciate Furra College which is the top per-public higher education institutions in Ethiopia that striving to serve the community by providing trainings in both undergraduate and postgraduate programs in different fields and supporting problem solving research works thoroughly. Furra College is well known institution in Ethiopia by giving free of charge scholarship for the whole public. In addition, we would like to express my heartfelt thanks to the managing director of the Furra Institute of Development Studies and Education for initiating and appreciating our research work. Furthermore, we grateful to Barassa Balguda dean of Furra College Gudamale Campus for encouraging our research activity. In addition, we would like to express our thanks to all staff of Furra College
Gudamale campus. Last but not least, we also extend our heartfelt thanks to the editors and the anonymous reviewers for their guidance and constructive comments in developing this article.

\section{References}

[1] Alemayehu Yirsaw. (2008). The performance of Micro Finance Institutions in Ethiopia: A case of six microfinance institutions Addis Ababa, April, 2010.

[2] AEMFI . (2009). Financial Needs of Micro and Small Enterprise (MSE) Operators in Ethiopia' Occasional Paper No. 24.

[3] Arsyad, L. (2005). An assessment of Microfinance Institution performance: The Importance of Institutional Environment: Gadjah Mada International Journal of Business, SeptemberDecember 2005, vol. 7, No. 3, pp, 391-427.

[4] Adeno K. (2007). Outreach and Sustainability of the Amhara Credit and Saving Institution (ACSI), Ethiopia. A Masters Thesis; Department of International Environment and Development Studies (Noragric) Norwegian University of Life Sciences (UMB), May 2007.

[5] Beaudry, S. (2008). Microfinance: A guide for grant makers.. [Online] Available at: http://www.gwob.net/news/GWOB Microfinance Guide.pdf [Accessed 6, 1, 2017].

[6] Befekadu B. Kereta . (2007). Outreach and Financial Performance Analysis of Microfinance Institutions in Ethiopia. African Economic Conference United Nations Conference Center (UNCC), Addis Ababa, Ethiopia 15-17 November 2007.

[7] CGAP, . (2016). Measuring microcredit delinquency.

[8] Cronbach's, L. J. (1951). Coefficient alpha and the internal structure of tests": Psychometric, 16, pp. 297-334.

[9] Nawai, N. and Shariff, M. N. M. (2013). Loan Repayment Problems in Microfinance Programs that use Individual Lending Approach: A Qualitative Analysis. Journal of Transformative Entrepreneurship, 1 (2), pp. 93-99.

[10] Reta, F. (2011). Determinate of Loan Repayment Performance: A Case Study of The Addis Credit and Saving Institution (ADCIS) In Addis Ababa.

[11] Samuel Setargie Amera (2008). Credit Default Risk and Its Determinants of Microfinance Industry in Ethiopia.

[12] Samuel, S. A. (2011). Credit default risk and its determinants of microfinance industry in Ethiopia.

[13] Smoradova, B. (2010). History of microfinance and comparison of Grameen Bank and BancoSol..[Online] Availableat:

http://www.grameeninfo.org/index.php?option=com content\& task $=$ view\&id=26\&Itemid=175. [Accessed 01 2017].

[14] Taro Yamane. (1967). Introduction to statistics $2^{\text {nd }}$ Edition. 